\title{
Heat Shock Protein 90
}

National Cancer Institute

\section{Source}

National Cancer Institute. Heat Shock Protein 90. NCI Thesaurus. Code C17766.

A family of structurally related proteins that play a role in cell signalling, protein folding and cellular stress responses. The members of this family are approximately $90 \mathrm{kDa}$. 